\title{
Being a Role Model to Motivate Students
}

\author{
Mega Wati \\ English Education Study Program \\ Universitas Kristen Duta Wacana \\ Yogyakarta, Indonesia \\ megawati@staff.ukdw.ac.id
}

\begin{abstract}
How can non-English students in a noncredited English program, who are thus usually reluctant, be encouraged to apply the university value of Striving for Excellence? In this paper the result is shared. This classroom research initially aims at identifying the successful motivational strategy from the students' points of view, and is implemented by making use of open-ended questions and qualitative data analysis. The subject of the research is the Theology students taking the English subject of Integrated Reading in the First Semester of 2013/2014 Academic Year. The finding shows 9 successful motivational strategies, i.e. telling motivational stories, advising, giving inspiring quotes, selecting reading texts with certain topics, giving comprehensive and detailed syllabus, making use of various teaching techniques, adopting certain teaching style, teacher's personality, and being a role model in showing integrity. Surprisingly, the last three strategies are equally as influential as the other 6 motivational strategies in the students' view. This becomes an evident that being a role model is a powerful motivational tool.
\end{abstract}

Keywords-a role model in education, character building, classroom research, motivational strategies, teaching by giving a model

\section{INTRODUCTION}

How to motivate students is a never-ending topic for discussion and research in education.[1] A reason for this may be that teacher skills in motivating students should be seen as central to teaching effectiveness.[2] There are countless studies and experiments confirming that students' motivation is the key to teaching and learning. Classroom researches on motivational strategies have also been done so as to-among others--find out how teachers impact students' motivation, prove that some motivational strategies are culture-sensitive or even culture dependent, and underscore the importance of including students' perspectives on identifying motivational strategies in classroom practices[3] [4] [5] [6].

None of those, however, has dealt with how teachers can be a powerful motivational tool by being models as Brophy stated: [7]

You-your own personality and everyday behavior in the classroom-can become your most powerful motivational tool. To do so, you will need to caltivate and display the attributes of individuals who are effective as models and socializers.

Nor those researches discussed the question about which is more influencial in generating students' motivation: motivational strategies that the teachers manipulate or the teachers themselves as a person? Another critical thing to ask is concerning Palmer's premise that good teaching cannot be reduced to technique because good teaching actually comes from the identity and integrity of a teacher [8]. If these questions are addressed, there could be an important implication for education in general, especially education in Indonesia, which is directed into the policy of teacher reform, that is to enhance the quality of teachers in order to improve the quality of education [9].

Then, the result of this classroom research can serve as a small evidence in adressing the above questions. In an attempt to arouse the usually-reluctant students of non-English department who have to take 3 semesters of obligatory noncredited English reading classes, the classroom teacher was humbled to find out that her being a role modeleventhough she did not plan this consciously-has generated her students' motivation in learning and in striving for excellence during the semester. Relevance and recommendation are included at the end of this report to give more contribution.

\section{METHODS}

Since each teacher in our university has to embed the core values into their teaching, the classroom teacher decided to specifically adopt the value of Striving for Excellence as the target of the motivational strategy. Therefore, the research questions are (a) Did the teacher succeed in motivating the students to do their best during the semester? (b) What motivational strategy is successful for that purpose? Why?

The subject of the study is 18 first-semester Theology students who were taking a reading matriculation program: an obligatory noncredited subject called Integrated Reading Class. In this class, students learn and practice reading techniques by doing pre- and post-reading activities such as watching a movie clip, discussing a song, writing a personal journal, and doing presentation. Reading materials are selected from authentic materials that will allow students as readers to widen their horizon, to enhance awareness towards life values, and to develop good character. Reading is done inside as well as outside the class through assignments and project. At the end of the semester the students are expected to be able to demonstrate their comprehension of English texts using appropriate reading techniques.

The data collection was implemented at the end of the first semester by giving the students a questionnaire with 2 open- 
ended questions containing the reseach questions stated previously, in which they can identify one or more effective motivational strategy. The questions were in Indonesian language, the students' lingua franca, to ensure comprehension to the qestions and capability in expressing themselves when answering the questions.

The feedback, then, was analyzed qualitatively in two ways. First, the responses were classified according to the similar keywords used by the students, such as telling inspiring stories, advising, motivational words, selected reading materials, and comprehensive syllabus. Second, similar responses are categorized and labeled, in this case, into 3 , i.e.teaching style, personality, and being a role model. To confirm the analysis and to gain more information, some students were informally interviewed.

\section{RESULTS AND DISCUSSION}

The questions that were given to the students at the end of the semester to uncover their perception are as follows when they are translated into English:

1. Do you think your teacher succeeded in encouraging you to do your best in the whole semester?

2. Which of the teacher's strategies did you find effective to motivate you to do your best throughout this semester? Why?

From the responses, it was clear that all students thought the teacher succeeded in motivating them to do their best throughout the semester, as seen in table 1.

TABLE I. SUCCESS IN MOTIVATING STUDENTS

\begin{tabular}{cccc}
\hline \multicolumn{4}{c}{$\begin{array}{c}\text { Do you think your teacher succeed in encouraging you to do your best in } \\
\text { the whole semester? }\end{array}$} \\
\hline Yes & Percentage & No & Percentage \\
18 & $100 \%$ & 0 & $0 \%$ \\
\hline
\end{tabular}

When the responses were further analysed by classifying them based on the keywords used, 6 motivational strategies were identified as shown in Table 2 with the information of their frequency. The 6 successful strategies are giving comprehensive syllabus and rubric from the very beginning and refering to these often; sharing stories of personal experience or others'; selected topics of reading texts used in class as well as assigned; varied teaching techniques; giving advise instead of reprimand when the students were slack; and using motivational quotations such as "That which does not kill you should make you stronger" (Friedrich Nietzsche) and "Excellence is not an act; it's a habit." (William Durant).

Then, when the rest of the responses are examined, it turned out that they can be categorized and labeled into 3, i.e. teaching style, teacher's personality, and teacher's being a role model. The frequency of these responses are also shown in table 2 .

\section{TABLE II. IDENTIFICATION OF SUCCESSFUL MOTIVATIONAL STRATEGIES}

\begin{tabular}{|c|l|c|}
\hline No & \multicolumn{1}{|c|}{ Motivational Strategy } & Frequency \\
\hline $\mathbf{1}$ & Comprehensive syllabus & 1 \\
\hline $\mathbf{2}$ & Telling stories & 2 \\
\hline $\mathbf{3}$ & Reading Texts & 3 \\
\hline $\mathbf{4}$ & Various teaching techniques & 3 \\
\hline $\mathbf{5}$ & Giving advise & 4 \\
\hline $\mathbf{6}$ & Motivational quotation & 4 \\
\hline $\mathbf{7}$ & Teacher's personality & 5 \\
\hline $\mathbf{8}$ & Teaching style & 6 \\
\hline $\mathbf{9}$ & Being a role model for integrity & 6 \\
\hline
\end{tabular}

It is clearly observed from the frequency of the responses in Table 2 that there are totally 34 responses, falling into 2 categories: what the teacher did (identified motivational strategies 1-6; 17 responses), and who the teacher was (identified motivational strategies 7-9; 17 responses). There are certainly various techniques to motivate students and retain it so that they participate actively in learning. Dornyei [10] stated that "... the best motivational intervention is simply to improve the quality of our teaching." However, it is also evident that in the students' perception, teacher's personality, her teaching style, and her ability to become a role model are equally as influencial in motivating them to do their best.

Some of this finding is beyond the teacher's expectation. In giving the students open-ended questions instead of multiple choice ones, she intended to give a chance to the students to self-reflect and to have freedom to identify and name the teacher's strategy in motivating them to do their best. Their answers in identifying the first until the sixth strategies were expected and therefore confirmed the teacher's belief that these were effective motivational strategies for classroom use, which was why she planned these from the very beginning. She only wished that more students had picked comprehensive syllabus as one of the effective strategies. She was also disappointed to find out that no one thought of her ways of complimenting them and occasionally showing in class their online progressive scores as motivational. However, the finding of the last three strategies with the highest frequency (i.e. teacher's personality, teaching style, being a role model for integrity) was not expected, since these were not consciously planned by the teacher. As she reflected on her teaching, she was humbled to realize that her whole being as a teacher mattered in making a difference in her students. This realization also confirms that more than 'merely' motivational strategies-i.e methods and techniques to generate, enhance, and maintain motivated behavior [1]teacher's personality and teaching style are also stated as factors for students' motivation.

Just as Brophy [7] further exemplified the effective attributes as models, Renandya [11] with his 5 Ts of Motivation also clarified the qualities of Teacher (T1). They referred to teachers who are friendly, caring, emotionally mature, supportive, humorous, enthusiastic, sincere, helpful and committed, who has a genuine interest in their students' learning and general well-being, and who has good rapport with them. The students' responses bear some of those attributes, but in their own terms, e.g. spirited, firm, fair, 
humorous, crazy, honest, creative, and sociable with young people. With these attributes, the teacher can have good rapport with her students, set up a good atmosphere for their learning, so that the students can respect their teacher, think positive about what she teaches, and--all in all--believe that their teacher has commitment for her students' interest [7].

The last identified strategy in this research that is appealing is the teacher's capability to become a role model in showing integrity. In their responses, 6 students $(30 \%)$ wrote that the teacher did what she said and taught to them so that they were willing to change for the better such as not to come late to class, or to work hard on writing journals in English. Two students even wrote that because they saw the teacher's integrity, they were motivated to do better. A deeper informal interview resulted in examples of being the model of integrity these students meant: when the teacher told them not to come late, she never came late; when she told them to work hard on assignments, she corrected the assignments and always returned their reviewed assignments a week later as promised. This finding is an important phenomenon in this research, indeed.

The premise that being a role model is an effective motivational tool [7] is presented couragiously in his own words [8]. He said that

Good teaching cannot be reduced to technique; good teaching comes from the identity and integrity of the teacher.

Concerning the above statement, he explained further the two terms of identity and integrity. What he meant by identity is the dynamic connection between the internal drive and the external drive of a person, in which the internal drive is the natural and genetic aspects in a person, while the expernal includes the culture where someone is brought up, other people who positively or negatively interact with him/her, as well as what he/she does and experiences in life. This interconnection between those two factors is what makes a person who he/she is, without ignoring the fact that those factors indeed meet in the whole human mystery. Meanwhile, integrity is defined as the unity that someone can find from all the interconnection of the two internal and external factors of his/her being.

$\mathrm{He}$, therefore, affirmed that "good teaching comes from good people" who have characteristics of good teachers, which is the ability to relate 3 aspects: his/her own person, the subject he/she teaches, and his/her students. Good teachers are able to weave a multifaceted web of the three in such a way that will empower the students to weave their own identity and integrity. In doing so, the teachers do make use of methodology in their teaching, but more than that, these good teachers do the weaving with their heart-where intellect, emotion, will, and spirit unite in their humanity [8]. This certainly explains the situation where the students of this classroom research were encouraged to do their best by observing the teacher's identity and integrity, as written by one of the students as follows:

What she said and taught, she did, so that it motivated me to do as she did.
This evident leads to the affirmation of teachers' role as educators. With the concept of Leading from Within [12] and Inside Out [13], teachers as educators, who belong to the leading community are invited to observe the depth of themselves [12] or-in other words - to develop self awareness [14], in order to make a responsible choice about what they intend to project to the outside world. Do you project enthusiasm or frustration to your class? [15] [7] [11] Do you send a message of truth or ambiguity? Do you show emotional maturity or broken personality? [12] [7] This kind of questions - or choices - should be asked to teachers, both preservice and inservice teachers, to ensure the quality improvement in education in Indonesia through the quality enhancement of teachers [9]. When teachers become good people [8], they can teach good characters such as being religious, noble, creative, independent, and responsible [16] through the methodology of being models [17] [8]. This classroom research has also made the teacher aware that the transfer of core values of the university, e.g. Striving for Excellence, that she picked as the target of the motivation enhancement for her class, can take place when she becomes an effective model.

\section{CONCLUSION}

This classroom research, which was initially intended to find out which motivational strategies are effective from the students' point of view, has turned out to give an important evident that being a role model is an effective motivating strategy, as effective as making use of other motivational tools to improve teaching quality. This finding has an impact on how important it is to inspire and empower teachers to develop not only their professional skills, but also their personality and integrity. Only by being the best version of themselves [14] can teachers be the most powerful motivational agent [7] for their students. Moreover, the outcome and impact of this kind of motivational strategy can be important, when it not only motivates the students to learn during the semester, but also inspires them to transform themselves for the better. Therefore, it is necessary to prepare preservice and inservice teachers to both improve their quality of teaching and improve their identity and integrity to be effective models for their students.

\section{ACKNOWLEDGMENT}

The author thanks all the 18 students who became the subjects of this research, who already inspired their teacher to keep working on her interior life and mission to become an effective model in education.

\section{REFERENCES}

[1] Z. Dornyei and E. Ushioda, Teaching and Researching Motivation, 2nd ed., Harlow: Pearson Education Limited, 2011.

[2] D. Thanasoulas, Motivation and Motivating in the EFL, [online, 17 January 2014], accessed from http://www.englishclub.com/teflarticles/motivation-motivating-efl.htm 
[3] A. Ruesch, J. Brown and D.P. Dewey, "Student and teacher perceptions of motivational strategies in the foreign language classroom", in Innovation in Language Learning and Teaching, vol. 6, No.1, March 2012, pp. 15-27.

[4] H-F Cheng and Z. Dornyei, "The use of Motivational Strategies in language instruction: The case of EFL teaching in Taiwan", in Innovation in Language Learning and Teaching, vol. 1, No.1, 2007, pp. 153-174.

[5] M. Sugita and O. Takeuchi, "What can teachers do to motivate their students? A classroom research on motivational strategy use in Japanese EFL context", in Innovation in Language Learning and Teaching, vol. 4, No.1, March 2010, pp. 21-35.

[6] M. Sugita and O. Takeuchi, "Motivational strategies in EFL classrooms: How do teachers impact students' motivation?", in Innovation in Language Learning and Teaching, vol. 8, No.1, 2014, pp. 20-38.

[7] J. Brophy, Motivating students to learn, 2nd ed., New Jersey: Lawrence Erlbaum Associates, Inc., 2004.

[8] P. J. Palmer, The courage to teach, San Francisco: Jossey-Bass Inc., 1998.

[9] M.C.Chang, S.Shaeffer, S. Al-Samarrai, A.B. Ragatz, J de Ree, and R. Stevenson, Teacher Reform in Indonesia: The Role of Politics and Evidence in Policy Making, Directions in Development, Washington, DC: World Bank. Doi: 10.1596/978-0-8213-9826-6, licence: Creative Commons Attribution CC BY 3.0.

[10] Z. Dornyei, Motivational strategies in the language classroom, New York: Cambridge University Press, 2001.

[11] W.A. Renandya, "Motivation in the language classroom", Singapore: Nanyang Technological University, in press.

[12] P.J. Palmer, Leading from within, Indianapolos: Lily Endowment, Inc., 1990.

[13] S. Covey, The 7 habits of highly effective teens, New York: Fireside Rockefeller Center, 1998

[14] R.I Chandra, Transformasi dari kepompong ke langit biru, Jakarta: Binawarga, 2000.

[15] A. Bishay, "Teacher motivation-Job satisfaction: A study employing the Experience Smapling Method", J.Undergrad. Sci., vol 3, Fall 1996, pp.147-154

[16] G. Raka et al., Pendidikan karakter di sekolah: Dari gagasan ke tindakan, Jakarta: Elex Media Komputindo, 2011.

[17] D.A. Koesoema, Pendidikan karakter, strategi mendidik anak di jaman global, Jakarta: Grasindo, 2007. 